\title{
D.J. Smit
}

\section{OOR DIE TEOLOGIESE INHOUD VAN DIE BELYDENIS VAN BELHAR ${ }^{1}$}

\begin{abstract}
The essay argues that the theological content is indeed the most important contribution of Reformed confessional documents, but that the theological content can only be understood against the specific historical, which most often means socio-political, circumstances in which these confessions were originally adopted. Regarding the Confession of Belhar, the theological content consists in three confessional claims (each including allusions to the false teaching that is implicitly thereby unmasked and rejected) within the broader framework of an introduction and conclusion, involving key theological claims as well, respectively about the nature of the church and the lordship of Jesus Christ. After some interpretive comments on all five of these structural aspects - the introduction and conclusion and the three claims - brief consideration is given to the nature of reception of confessional documents in the Reformed tradition and some implications for the reception of the theological content of the Confession of Belhar.
\end{abstract}

1 Hierdie bydrae is 'n verwerking van 'n voordrag wat op 31 Oktober 2011 op uitnodiging gelewer is tydens die Fakulteit Teologie van die Universiteit van die Vrystaat se openbare konferensie ter herdenking van die 25-jarige aanvaarding van sowel die dokument Kerk en Samelewing deur die NGK asook die amptelike aanvaarding van die Belydenis van Belhar deur die (destydse) NGSK. Die tema van die konferensie was “'n Blik op Eenheid, Versoening en Geregtigheid 1986 en 2011" en die uitnodiging was spesifiek om te praat oor "die teologiese inhoud van die Belydenis van Belhar."

Prof D.J. Smit, Fakulteit Teologie, Universiteit van Stellenbosch.

E-pos: djs1@sun.ac.za.

Acta Theologica

2012 32(2): 184-202

DOI: http://dx.doi.org/10.4314/actat.v32i2.11

ISSN 1015-8758

(C) UVIUFS

<http://www.uovs.ac.za/ActaTheologica> 


\section{ALGEMENE OPMERKINGS OOR DIE TEOLOGIESE INHOUD}

Die betekenisvolle aan enige Protestantse belydenisskrif is inderdaad die teologiese inhoud. Belydenisskrifte is en word altyd gebore in spesifieke sosiale en historiese omstandighede. Die politieke en kerklike konteks bied feitlik altyd die konkrete aanleiding waarom belydenisskrifte ontstaan. Dit geld van haas elkeen van die veel meer as honderd belydenisskrifte wat vroeg reeds binne die Gereformeerde gemeenskap en tradisie gebore is, asook van die belydenisse wat daarna geskryf sou word, omdat só 'n reaksie van die geloof op spesifieke politieke en historiese uitdagings telkens deur sommige as noodsaaklik beleef is. Dit geld van die Geneefse Kategismus, van die Franse Geloofsbelydenis, van die Nederlandse Geloofsbelydenis, van die Heidelbergse Kategismus, van die Skotse Konfessie, van die Dordtse Leerreëls, van die Westminster Konfessie - en dit geld ook van die Teologiese Verklaring van Barmen, van die Confession of 1967 van die Presbiteriane in Amerika, van die Brief Statement of Faith van die PCUSA en van die Belydenis van Belhar. ${ }^{2}$

Gelowiges bely meesal hulle verstaan van die evangelie opnuut in die aangesig van wat hulle as ' $n$ konkrete oomblik van waarheid ervaar. In die gewone gang van sake bely hulle dit in die woorde van die tradisie en die bestaande belydenisskrifte, maar in 'n buitengewone oomblik - soms beskryf as 'n status confessionis, 'n toestand van belydenis, waarin die verstaan en verkondiging van die evangelie sélf te omstrede en ongeloofwaardig geword het - kan Gereformeerde gelowiges oordeel dat ' $n$ oomblik van nuwe belydenis vir hulle aangebreek het, ten einde onderskeiding te bring in dié situasie van verwarring en verdeling. ${ }^{3}$

Dit beteken dat die inhoud van Protestantse belydenisskrifte nie verstaan kan word los van dié historiese oomblikke nie. Hulle is almal pogings om in konkrete situasies die evangelie opnuut te bely - gegee die uitdagings van die tyd, die veronderstellings en die voorstellings, die standpunte en strydgesprekke, die taalgebruik en konsepte van die tyd. Sulke belydenisse is nie a-historiese, tydlose en kontekslose dokumente met ewige en finale formulerings, wat net só en nie anders gestel kan en moet word nie. Die inhoud van sulke belydenisse lê in hulle strekking, in hulle religieuse motiewe, in hulle geestelike beslissings, in die insigte wat

2 Oor die aard en inhoud van die Gereformeerde belydenistradisie, sien byvoorbeeld die bespreking en uitvoerige literatuur by Smit 2006a, en meer volledig Jonker 1994.

3 Oor die voorstelling en funksie van 'n status confessionis, sowel in die vroeër Protestantse geskiedenis as in die 20ste eeu, sien Smit 1984. 
hulle oor die evangelie wou verwoord in hulle spesifieke kontekste, in die oortuigings wat hulle wou bely téénoor misleidende oortuigings in die lug - soos wat Berkouwer helder sou aantoon. ${ }^{4}$

Dit beteken tegelyk dat wat wél belangrik is inderdaad die teologiese inhoud is, die bedoeling en strekking, die geestelike beslissings, die religieuse motiewe, die aansprake aangaande die evangelie, die oortuigings van die geloof. Die waarheid van belydenisskrifte hang nie af van die historiese oomblik, van moontlike nuttigheid en betekenisvolheid vir die sosiale, politieke en kerklike konteks nie, van potensiële gedienstigheid aan ander strewes en motiewe nie, maar uitsluitlik van die vraag of die evangelie in dié oomblik van omstredenheid reg gehoor word, of nie. ${ }^{5}$

Om dié rede bevat sulke Gereformeerde belydenisskrifte meesal begeleidende voorwoorde, inleidings of briewe, waarin die motiewe, bedoelinge en verwagtinge agter dié daad van belydenis verduidelik word, teen die agtergond van die konkrete omstandighede, en waarin susters en broers genooi word om saam te oordeel of die evangelie inderdaad reg gehoor is en bely word, of nie. ${ }^{6}$

Ook die Belydenis van Belhar is gebore in so ' $n$ historiese oomblik, van apartheid en van die Bybelse en teologiese regverdiging van apartheid binne die kerk self. Sonder dié politieke en kerklike agtergronde was daar geen Belhar nie en sonder die teologiese debatte van destyds kan die ontstaan van Belhar nie na behore verstaan word nie. ${ }^{7}$ Tegelyk is die waarheid van Belhar, die geloof en teologiese inhoud wat bely word nie van apartheid en sy regverdiging afhanklik nie. Die waarheid van 'n belydenisskrif is nie die waarheid van die historiese omstandighede nie, maar die waarheid van die evangelie vir die historiese omstandighede.

Die vraag is dus of die teologiese inhoud ook onder ander omstandighede steeds en oral waar sou wees en bly, omdat dit inderdaad

$4 \quad$ Sien die indringende analise van die funksie van belydenisskrifte in Berkouwer 1963.

5 Vir 'n verhelderende bespreking van die inhoud en rol van Protestantse belydenisskrifte as "bevrydende waarheid," sien Jonker 1994.

6 Vir die begeleidende briewe of voorwoorde van die sogenaamde Nederlandse formuliere van eenheid, sien byvoorbeeld Bakhuizen van den Brink 1976:6069 (vir die Nederlandse Geloofsbelydenis), 1976:150-153 (vir die Heidelbergse Kategismus) en 1976:226-229 (vir die Dordtse Leerreëls). Vir die begeleidende woorde tot die Teologiese Verklaring van Barmen, sien byvoorbeeld Burgsmüller \& Weth 1998:32-35.

7 Vir die historiese agtergronde van die Belydenis van Belhar, sien byvoorbeeld Cloete \& Smit 1984; Botha \& Naudé 1998, 2010; Naudé 2010. 
die waarheid van die evangelie en die Skrifte self is, wat ook onder ander omstandighede en in nuwe situasies - selfs onverwags en verrassend nuwe toepassings en aktualiteit mag vind, soos wat die belydenistradisie altyd funksioneer. Dis om dié rede dat die NGSK-Sinode in 1982 uitdruklik besluit het om die woord apartheid nêrens in die Belydenis te gebruik nie. Soos alle Gereformeerde belydenisskrifte is Belhar wel opgeroep in 'n konkrete oomblik, maar hang die teologiese inhoud en aansprake op blywende waarheid nie daarvan af nie. Wat omstrede was, wat ten diepste op die spel was, was inderdaad teologiese inhoude, vrae oor die verstaan van die evangelie en oor die geloofwaardigheid van die kerk se verkondiging en lewe.

Dus, wat is hierdie teologiese inhoud, hierdie geestelike strekking en religieuse motiewe? Die Belydenis is doelbewus baie eenvoudig, sowel wat struktuur, taalgebruik en argument betref. ${ }^{8}$ Die Sinode se opdrag was om te probeer bely waarom die kerk ná jare van debat nou met die ekumeniese kerk saamstem dat die geloofwaardigheid van evangelie self hier op die spel was. Die kommissie het besef dat dit nie 'n oomblik was vir theolegoumena, vir nuwe teologiese argumente nie, maar inteendeel 'n oomblik om te probeer verwoord watter geestelike oortuigings reeds in die harte van lidmate leef, op grond waarvan hulle apartheid met sy Bybelse regverdiging verwerp het.

Drie sake was dadelik duidelik, naamlik dat dit strydig was met diepgewortelde oortuigings aangaande die eenheid van die kerk, die versoening in Christus en die geregtigheid van God. Dié drie temas sou daarom die struktuur van die Belydenis bepaal.

By elkeen sou bely word wat die kerk wél glo - omtrent eenheid, versoening en geregtigheid - en by elkeen sou dan ook gesê word watter oortuigings in die lug die kerk gevolglik verwerp, soos byvoorbeeld ook in Dordt en Barmen.

Omdat 'n geloofsbelydenis iets anders is as 'n kerklike verklaring of ' $n$ teologiese studiestuk word by elkeen van die drie temas in die eerste plek lofseggend bely wie die Bybelse God is en wat die Bybelse God dóén. ${ }^{9}$ Hierdie God is die Een wat eenheid, versoening en geregtigheid skénk.

8 Vir meer uitvoerige analises van die inhoud van die Belydenis van Belhar, sien byvoorbeeld Botha \& Naudé 2010; Naudé 2010.

9 Sien byvoorbeeld hieroor Van Ruler 1954:14: "Het doel van het belijden ligt in (God). Anders gezegd: in de lofzegging, in het lofzeggend begeleiden van de levende God in zijn gang door de tijd. De grondtoon van alle belijden heeft daarom iets feestelijks. Het is lyriek der liefde." 
Omdat dit 'n Gereformeerde belydenis is, word by elkeen van die drie temas dan bygevoeg dat hierdie God ons roep om óók so te lewe en doen, hierdie eenheid, versoening en geregtigheid moet ook nagejaag en beoefen word, die roeping tot navolging vloei uit die gawe, ons dissipelskap volg uit die belydenis dat ons nie aan onsself behoort nie, maar aan hierdie Drie-enige God. ${ }^{10}$

Hierdie drie temas word voorafgegaan en gevolg deur 'n kort aanhef en slot. Sowel die aanhef as slot is egter meer as blote terloopse byvoegings. Albei maak aansprake wat sowel in die Gereformeerde tradisie asook in die spesifieke historiese oomblik van Belhar se ontstaan swanger aan betekenis en implikasies was. Albei behoort dus onlosmaaklik tot die teologiese inhoud of die geestelike beslissings van die Belydenis.

Teen die agtergrond van hierdie algemene opmerkings kan volstaan word met vyf kort punte oor die teologiese inhoud van Belhar. Die eerste punt handel oor die aanhef en slot as integrale deel van die religieuse motiewe. Punte twee tot vier handel agtereenvolgens oor die temas van eenheid, versoening en geregtigheid, terwyl punt vyf kortliks nadink oor resepsie van dié teologiese inhoud.

\section{OOR DIE TEOLOGIESE INHOUD VAN DIE AANHEF EN SLOT}

Sowel die aanhef as die slot sluit doelbewus aan by die Gereformeerde belydenistradisie en wek assosiasies met ander belydenisskrifte. Die aanhef bely in die gees van 16 e eeuse belydenisskrifte dat die Drie-enige God self deur sy Woord en Gees die kerk versamel, beskerm en versorg van die begin van die wêreld af tot die einde toe. Dié woorde mag dalk vandag algemeen en byna onskuldig klink, maar in die destydse konteks was dit allesbehalwe.

Daar agter skuil dekade-lange debatte rondom die Gereformeerde verstaan van die kerk tussen volkskerk en belydeniskerk. Daar agter skuil die vrae watter kragvelde - soos dit later genoem is - werklik die lewe van die kerk bepaal het, trou aan die belydenistradisie of verbondenheid met volksgroep en kultuurverband. Daar agter skuil intense teologiese debatte oor die vraag of liberale kerkreg, waarvolgens die kerk 'n vrye assosiasie van gelykgesindes is (met die moontlikheid van die uitsluiting van ander) nie die oorhand gekry het binne die NG-kerkfamilie

10 Vir ' $n$ bespreking van die etiese implikasies van byvoorbeeld die Heidelbergse Kategismus, sien Verhey 1986. 
bo die tradisies van Gereformeerde kerkreg nie. Daar agter skuil die omstredenheid of nasionalistiese strewes vanuit die $19 \mathrm{e}$ eeuse romantiek en kultuurprotestantisme nie die gestalte van die kerk bepaal het, eerder as die evangelie nie. Daar agter skuil die afwysing van ontwikkelinge wat stap vir stap sou volg op die bekende 1857-besluit oor die swakheid van sommige wat die gestalte van die gemeentelike aanbidding mag stempel. ${ }^{11}$ Daar agter skuil die aansprake van die Teologiese Verklaring van Barmen met sy derde tese waarvolgens die kerk met boodskap én orde behoort te getuig dat dié aan Jesus Christus behoort en dat dit die kerk dus nie vrystaan om óf sy boodskap óf sy orde te laat bepaal deur heersende ideologiese en politieke oortuigings nie. ${ }^{12}$

Kortom, alhoewel die implikasies nie uitgespel word nie en daar geen afwykende oortuigings uitdruklik aangedui word nie, was die retoriese strekking van hierdie inleidende woorde glashelder en radikaal. Dit was die keuse om saam met die Gereformeerde belydenisskrifte oor die kerk te dink eerder as saam met die liberale kerkreg en die heersende politieke ideologie. Die kerk is die kerk van Jesus Christus en nie van die volk nie. Die kerk behoort aan die Drie-enige God en dié belydenis het radikale implikasies ook vir die gestalte en orde van die kerk. 'n Mens sou kon sê dat die grondtoon van die res van die Belydenis reeds hier in die aanhef weerklink.

Die slot bely eweneens doelbewus in die gees van $16 \mathrm{e}$ eeuse én meer onlangse belydenisskrifte. Die oortuiging dat Jesus Christus die Heer is aan wie die kerk gehoorsaamheid en navolging verskuldig is, selfs ondanks teenkanting en swaarkry, is diep verwortel in die Protestantisme. ${ }^{13}$ Trouens, volgens Jaroslav Pelikan is dit die inhoud van die heel vroegste belydenis van die kerk. ${ }^{14}$

11 Vir 'n soortgelyke argument oor die geskiedenis en die ekklesiologie wat op die spel was in hierdie debatte, sien byvoorbeeld die invloedryke behandeling in Jonker 1962.

12 Vir verbande tussen die Teologiese Verklaring van Barmen en die Belydenis van Belhar, sien byvoorbeeld Smit 2006b.

13 Oor die belangrike implikasies vir die Gereformeerde ekklesiologie van die manier waarop oor die heerskappy van Christus in die kerk gedink word, sien Jonker 1965. In die lewe en werk van Allan Boesak was dit 'n sleuteltema, sien byvoorbeeld sy eie outobiografiese terugblik 2009 - waar onder reeds al die heel eerste deel, onder die opskrif "not a single inch: faith and politics," wat klaarblyklik 'n verwysing inhou na Kuyper se bekende uitspraak oor die heerskappy van Jesus Christus oor elke duimbreedte van die werklikheid. Vir'n duiding van Boesak se werk in dié gees, sien byvoorbeeld Koopman 2012.

14 Sien uitvoerig Pelikan 2003, wat die heerskappy van Christus en die politieke agtergronde en implikasies van belydenisse ter sprake bring in meerdere kontekste van sy gedetailleerde argument. 
Die laaste Skrifwoord wat in Belhar by wyse van assosiasie opgeroep word, juis by hierdie belydenis dat Jesus die Heer is, is 1 Pet. 3:15-18. Die gemeente moenie vrees as hulle vervolg word ter wille van wat reg is nie, maar hulle moet Jesus Christus as Heer in hulle harte heilig en altyd bereid wees om met beskeidenheid en eerbied openbare rekenskap af te lê teenoor enigeen wat van hulle verantwoording eis oor die hoop wat in hulle lewe.

Ook hierdie assosiasie het diepe wortels in die Gereformeerde tradisie. Wanneer die Nederlandse Geloofsbelydenis (byna presies 450 jaar gelede) in die nag van 2 November 1561 oor die poort van die kasteel by Doornik gegooi word met 'n begeleidende brief, staan hierdie woorde op die buiteblad gedruk, van sowel die Franse as Nederlandse weergawes. ${ }^{15}$ Met die skryf van Belhar word hierdie woorde herhaaldelik nadruklik in die Sinode vermeld en gedokumenteer om die gees aan te dui waarin alles geskied. ${ }^{16}$

Met reg het Russel Botman onlangs geargumenteer dat 'n mens ook die hele Belydenis vanuit hierdie woorde, dat Jesus die Heer is, sou kon lees. ${ }^{17}$ Die grondtoon, die religieuse motief van die Belydenis, weerklink ook hier in die slot, soos reeds in die aanhef.

Binne dié teologiese raamwerk, wat 'n mens dalk oortuigings aangaande ware Christelike vryheid (die aanhef) en ware Christelike verantwoordelikheid (die slot) kon noem, ${ }^{18}$ alhoewel die terme nie self gebruik word nie, kom die drie temas van eenheid, versoening en geregtigheid dus ter sprake.

\section{OOR LEWENDE EENHEID}

Die oortuigings aangaande die eenheid van die kerk is baie eenvoudig. Miskien is drie opmerkings genoegsaam. In die eerste plek is die

15 Sien Bakhuizen van den Brink 1976 vir die oorspronklike voorblaaie van opeenvolgende uitgawes in verskillende tale, asook die uiters informatiewe Braekman \& De Boer 2011.

16 Sien Smit 2012 vir meerdere inligting en verwysings na die betrokke sinodale dokumente.

17 Sien Botman 2011, die weergawe van sy mondelinge bydrae tydens 'n paneelbespreking tydens die 2011 sinode-sitting van die NGKerk van Wes-en Suidkaap.

18 Vir die belang van dié twee sleutel temas vir die Protestantse etiek, sien byvoorbeeld Huber onderskeidelik 1985 en 1990. Vir Suid-Afrikaanse aansluiting deur etici by dié twee motiewe, sien byvoorbeeld Fourie 2011 (vir vryheid) en De Villiers 2007 (vir verantwoordelikheid). 
kerk volgens Belhar rééds een. Met assosiasies aan die Bybel, aan die ekumeniese credo's van die vroeë kerk, asook aan 16e eeuse belydenisskrifte word bely dat die eenheid van die kerk 'n gawe is. Vanuit die ganse menslike geslag roep God die een kerk, die gemeenskap van die heiliges. Deur die versoeningswerk van Christus en die samebindende krag van die Heilige Gees is die kerk een, as gawe. Die eenheid word nie deur ons geskep nie, word bely. Dis nie van ons afhanklik nie. Ons kan nie kies of ons een wil wees of nie wil wees nie. Ons ontvang mekaar, as susters en broers in Christus, kan mekaar nie kies en ook nie weier nie. Die dramatiese implikasies in die destydse konteks van die oortuigings wat hiermee bely word, spreek vanself.

In die tweede plek word bely dat hierdie gawe ook 'n opdrag is, die geestelike eenheid wat rééds werklik is behoort ook sigbaar uitgeleef te word, sodat die wêreld kan glo, tot lof van God. Alle kragte wat hierdie sigbare eenheid bemoeilik, tussen mense en mensegroepe, alle geskeidenheid, vyandskap en haat, is reeds deur Christus oorwin. Gelowiges durf nie opnuut aan hierdie kragte plek te gee in die kerk nie, maar kan dit met vertroue weerstaan en bestry. Weer eens is dit 'n oortuiging van groot belang in die Gereformeerde tradisie, soos reeds by Calvyn self, maar wat in die praktyk dikwels ontken en verloën is, sóós natuurlik ook in die oomblikke toe Belhar gebore is. ${ }^{19}$

Juis hierdie verloëning maak die derde punt nodig. In die derde plek word naamlik bely hoe die eenheid sigbaar behoort te word. Waarna behoort ons te strewe? Wat vra sigbare eenheid werklik? Belhar gaan op dié vraag in deur weer eens 'n drieërlei oortuiging te bely.

Die sigbare eenheid sluit ' $n$ ryke en wonderbare verskeidenheid in, nie uit nie - dis die eerste punt. Om dié oortuiging te verwoord word 'n lang lys van assosiasies gebruik, vanuit die Bybel en die belydenisskrifte, om gelowiges te herinner aan hoe ryk en kompleks die geleefde eenheid, die onderlinge liefdesbetoon, waarlik is.

Die sigbare eenheid kan slegs in vryheid gestalte kry, en nie afgedwing word nie - dis die tweede punt. ${ }^{20}$ Die verskeidenheid van geestelike gawes, geleenthede, agtergronde, oortuigings, asook van taal en kultuur, is vanweë die versoening in Christus geleenthede tot wedersydse diens en verryking binne die een sigbare volk van God, word bely. Dié tema was destyds hoogs omstrede. Verskeidenheid was immers die basis van die heersende

19 Vir Calvyn oor die eenheid van die kerk, sien byvoorbeeld Smit 2010 met literatuur.

20 Vir bespreking van die agtergrond van hierdie uitdrukking en sommige implikasies vir die Gereformeerde ekklesiologie, sien Smit 2006c. 
ideologie. In die 1982 Sinode was dié een van slegs twee formuleringe waarvan gevra is of die positiewe verwysing na verskeidenheid nie liefs weggelaat kan word nie, "omdat ons almal weet wat met verskeidenheid gemaak word," is gesê. Die Sinode het die woorde behou, "omdat ons nie vanweë ander se misbruik die waarheid kan ontken dat verskeidenheid deel is van Gods wonderbare genade, rykdom en seën nie."

Hierdie verskeidenheid en hierdie vryheid mag egter nie daartoe lei dat die eenheid later nie meer sigbaar is nie, dis verskeidenheid en vryheid "bínne die een sigbare volk van God" - dis die derde punt. Die wonderbare verskeidenheid en vryheid mag nie vertolk kan word as gestaltes van verdeeldheid en skeuring nie. Die eenheid is nóg uniformiteit, nóg bloot struktureel en organisatories. Die liggaam leef juis van verskeidenheid en onderlinge en wedersydse diens, in die plaaslike gemeente en in die kerkverband. Hier klop diepe oortuigings van die Reformasie. Die kerk is een as die evangelie reg gepreek en gehoor en die sakramente reg bedien word, leer Luther én Calvyn. ${ }^{21}$ Waar dit geld is ruimte vir veel verskeidenheid - van belydenisgrondslag, aanbiddingstyl, organisatoriese vorme - dog dit moet steeds onmiskenbaar duidelik bly dat dit gaan om één sigbare volk van God, sodat die wêreld kan sien en glo.

\section{OOR WARE VERSOENING}

Die oortuigings aangaande die versoening in Christus is eweneens baie eenvoudig. Vir die NGSK was dit egter van sleutel belang om te bely dat die versoening van Christus sterker is as natuurlike en kulturele verskille tussen gelowiges. Reeds vier jaar tevore, in 1978, het die Sinode immers geoordeel dat die Bybelse regverdiging van apartheid ten diepste berus op die oortuiging dat ons onderlinge kulturele verskille so groot is dat dit beter is as selfs Christene uiteen gehou word.

In Belhar word daarom bely dat die Bybelse God deur sy Woord en Gees by magte is om gelowiges se bitterheid en vyandskap te oorwin en die kerk in staat te stel tot 'n nuwe gehoorsaamheid. Indien ons dit by voorbaat nie sou glo en uitleef nie, maak ons die evangelie wat ons self verkondig ongeloofwaardig, omdat ons eie lewe dan die waarheid van ons eie getuienis weerspreek en verloën. ${ }^{22}$

21 Vir meer uitvoerige bespreking van Calvyn en die Gereformeerde tradisie in dié verband, sien Smit 2009a.

22 Oor die motief van versoening is daar veel geskryf, sien byvoorbeeld Smit 2009 b en veel vroeër 2000 a. 
In die destydse historiese konteks was dit nie maklik om versoening te bely nie. Dit was 'n hoogs omstrede saak, om véle redes - onder andere óók omdat sommige dit beskou het as 'n sinoniem vir wegkyk, die oë sluit, stilbly oor wat verkeerd is, as vergewe en vergeet en maak asof alles in orde is, ter wille van oppervlakkige vrede en goeie verhoudinge. Dit was daarom dikwels nodig om te kwalifiseer dat ' $n$ mens van ware versoening praat, nie van goedkoop versoening nie, van egte versoening, nie van oppervlakkige versoening nie, van daadwerklike versoening, wat die verlede nie ontken, die pyn nie verswyg, die bitterheid nie probeer verberg nie, maar van die ware versoening in Christus, waardeur die middelmure van skeiding afgebreek word en daadwerklik vrede gestig word.

Teologies uitgedruk roep die versoening in Christus om uitwerking in die geskiedenis, om verwerkliking, in die woorde van Willie Jonker, om verwesenliking, praktiese uitlewing, om beoefening, om beliggaming. ${ }^{23}$ Deur die werking van Gods Woord en Gees is dit moontlik, bely Belhar.

\section{OOR ONTFERMENDE GEREGTIGHEID}

Die oortuigings aangaande die Bybelse God se ontfermende geregtigheid was vir sommige dalk vreemder om te hoor. Weer eens kan drie opmerkings dalk help lig werp. In die eerste plek word hier roemend, doksologies, lofprysend oor Gód gepraat. In die Bybel is God se geregtigheid 'n reddende geregtigheid, 'n ontfermende geregtigheid, wat bevry uit nood en reg laat geskied aan die wat veronreg word. Dis die Bybelse God se trou aan sy eie verbond, aan sy beloftes en aan sy ewige liefde. Volgens die Bybelse tradisies hoor God die gebede van hulle in nood, sien God die lot van hulle wat verslaaf is deur sonde en swaarkry, en gee God om, gryp in, regverdig en heilig, vergewe en aanvaar, help en troos, uit ontfermende geregtigheid. Dit onderskei die Bybelse siening van geregtigheid van filosofiese teorieë oor geregtigheid.

In 'n wêreld vol onreg en vyandskap, is die Bybelse God die Hulp van die hulpelose, op 'n besondere wyse die God van die noodlydende, die arme en die veronregte. ${ }^{24}$ Die kerk loof God omdat God as só 'n God geopenbaar is. Dit was die tweede uitdrukking waarvan in die 1982 Sinode gevra is of dit nie gewysig kan word, ten einde bevrydingsteologiese taal te gebruik dat God die God van die armes is, of aan die kant van die armes

23 Vir Jonker se siening van die noue verband tussen belydenis en beliggaming of uitlewing, sien Smit 2002.

24 Vir ' $n$ vroeë bespreking van die Bybelse agtergronde en die formulering en bedoeling van dié belydenis, sien byvoorbeeld meer uitvoerig Smit 1982. 
nie. Weer eens het die Sinode die versoek afgewys, omdat gesê is dat dié oortuiging, dat God in 'n klassestryd kant kies en gevolglik vir sommige en teen ander is nie die geloof van die lidmate sou verwoord nie.

In die tweede plek word bely dat hierdie God die kerk, die gelowiges, roep om ook hierin na te volg. 'n Reeks Bybelse assosiasies herinner aan dié deurlopende Bybelse motief - deur die wet, die profete, die wysheid, die Evangelies, die Briewe. Geregtigheid, barmhartigheid, aanbidding - dié drie hoort byeen, as samevatting van die wet (Matt 23:23). ${ }^{25}$ Die kerk wat aan hierdie God behoort is geroep om te staan waar hierdie God staan. Dit hou in dat die kerk sal getuig teen onreg en teen alle magtiges wat uit selfsug slegs hulle eie belange sou soek al word ander daardeur benadeel.

In die derde plek beteken dit dat die kerk sal leer onderskei wanneer en hoe dit nodig is om teen onreg te getuig en vir geregtigheid te stry. In die Gereformeerde tradisie was dié oortuiging dikwels sterk - 'n mens dink aan Calvyn se eie iustitiae amor, die liefde vir die geregtigheid as samevatting van die Christelike lewe; ${ }^{26}$ aan Noordmans se aangrypende meditasie oor "zondaar en bedelaar"; ${ }^{27}$ aan Karl Barth se uitleg van die bede om die koninkryk - as fiat iustitia - in die Ons Vader gebed. ${ }^{28}$

Tog sou Barth self by geleentheid hom verwonder oor die wyse waarop die Westerse kerklike en teologiese tradisie ook dikwels hierdie fundamentele Bybelse oortuiging misgekyk het. ${ }^{29}$ Hoe is dit moontlik, vra hy, dat die Reformasie, en feitlik die hele vroeë en onlangse Protestantisme, hierdie dimensie van die evangelie kon miskyk wat tog so duidelik in die Nuwe Testament betuig word? Hy bedoel die insig dat die evangelie óók ' $n$ boodskap is van genadige en barmhartige bevryding uit die bande van dood en kwaad en uit die mag van boosheid. Dis trouens presies ook

25 Sien die herhaalde besprekings van die drievoudige spits van die wetgewing (in geregtigheid, barmhartigheid en trou of waarheid) by Welker 1986a, 1986b, 1993, 1994, 2002.

26 Sien byvoorbeeld Calvyn se uiteensettings van die wet, die Christelike lewe en die Christelike vryheid in die Institusie (Calvyn 1960), en vir besprekings byvoorbeeld Smit 2003a, 2005b, 2005a, 2007, 2009c, ook 2011.

27 Oorspronklik uit 1946, maar later weer uitgegee as deel van sy versamelde werk, in Noordmans 1980:15-25.

28 Sien Barth 1981, en vir besprekings byvoorbeeld Smit 2004, 2009d, ook Boesak 2011.

29 Vir 'n bespreking van hierdie problematiek binne Barth se Christologie, sien Smit 1988 en 2003b. 
Noordmans se punt oor Lasarus, "Er is in het Evangelie nog meer dan de kerk zich daaruit heeft toegeëigend." 30

Juis om dié rede was dit vir baie gelowiges in hierdie tradisies ook dalk aanvanklik vreemd toe Belhar bely dat die Bybelse God op 'n besondere wyse die Hulp van die hulpeloses is, die Vader van die wees en die Eggenoot van die weduwee, in die woorde van Guido de Brés, die ontfermende God van noodlydendes, armes en veronregtes. ${ }^{31}$

\section{OOR DIE ONTVANGS, UITLEG EN UITLEEF VAN DIE TEOLOGIESE INHOUD}

Enkele kort opmerkings oor die resepsie van hierdie teologiese inhoud dien as afsluiting. Dis oombliklik duidelik dat dit onmoontlik is om die volle teologiese inhoud saam te vat, op te som, as 't ware in ander woorde kortliks weer te gee. Dit geld van alle belydenisskrifte. Met die blote struktuur en met enkele kort opmerkings is alles nog hoegenaamd nie gesê nie, hoe nodig dit ook al mag wees. Daar word veel meer bely as wat in enkele sinne saamgevat kan word. Daarom moet 'n mens versigtig wees om nie belydenisskrifte te reduseer tot enkele slagspreuke - soos uitverkiesing, eenheid, versoening en geregtigheid - en daarmee te dink dat alles gesê is nie.

Trouens, die resepsie van belydenisskrifte bestaan nie eens in die herhaling van die woorde, van die presiese formuleringe nie. ${ }^{32}$ Die ware ontvangs van belydenisskrifte het eerder te make met opnieude toeëiening van die geestelike motiewe, van die religieuse beslissings, van die teologiese keuses, wat destyds gemaak is en wat in die dokument gebrekkig en baie menslik - verwoord word.

Dit impliseer egter dat die nuwe uitleg en die nuwe toeëiening van dieselfde motiewe en beslissings in die aangesig van nuwe uitdagings en versoekings 'n integrale deel van egte resepsie word. Wie waarlik in 'n belydenistradisie staan probeer onderskei in die hede wat trou aan hierdie vroeëre geestelike beslissings vandag vra en verg.

30 Dis die laaste woorde van Noordmans se aangehaalde meditasie, Noordmans 1980:25.

31 Die woorde kom uit De Bres se bekende brief aan sy vrou vanuit die gevangenis, vir besprekings sien byvoorbeeld Braekman in Braekman \& De Boer 2011:114115; ook Polman s.a.:209-230, met die aanhaling op 230.

32 Oor resepsie, sien Naudé 2010:131-168; vroeër ook Naudé \& Smit 2000. 
Dit beteken boonop - ten minste wat betref Gereformeerde belydenisskrifte - dat die uitlééf in die hede die eintlike toetssteen word van ware resepsie en van trou aan die teologiese inhoud. Eberhard Busch het dit aangrypend duidelik gemaak aan die hand van die Teologiese Verklaring van Barmen. Belydenisskrifte hoort nie as pronkstukke in museumkaste nie, maar as baniere op die slagveld. ${ }^{33}$ Ware resepsie word sigbaar in die praktiese, konkrete uitlewing van die religieuse motiewe wat destyds op die spel was en dalk opnuut weer is, al is dit in nuwe gestaltes.

Calvyn sou dit ewe aangrypend duidelik maak aan die hand van 1 Pet 3 . Ons doen maklik verantwoording van ons hoop met die mond, sê hy, met gepraat en met baie woorde, maar veel moeiliker met ons lewe, met gedrag wat pas by dié belydenis. ${ }^{34}$

Dit sou maklik gedemonstreer kon word aan die hand van al drie die temas van Belhar. Op verskillende plekke - ook waar Belhar vandag op 'n verskeidenheid maniere geresepteer word - word gevra wat dié geestelike en teologiese oortuigings vandag beteken onder totaal ander en nuwe omstandighede, en wat getroue uitlewing, praktiese beliggaming, van dié teologiese inhoud vandag sou beteken. ${ }^{35}$

In die Gemeenskap van Protestantse Kerke in Europa (KEK) word byvoorbeeld gevra wat eenheid, koinonia, communio, gemeenskap waarlik vandag sou kon beteken. Die bekende motief van versoende verskeidenheid, "reconciled diversity," van eenheid-in-verskeidenheid, bied dalk te min, word vandag gesê, omdat dit maklik net 'n naam kan wees waar onder die verdelings van die verlede geregverdig word, sonder dat daar enige werklike versoening plaasvind en sonder dat die wêreld enigiets sien wat hulle kan help om te glo. Maar wat sou Belhar se verskeidenheid-ineenheid konkreet kon beteken, hoe sou dit prakties beliggaam en beoefen kon word, in die orde en in die lewe van die Protestantse kerke ${ }^{36}$ Presies dieselfde vrae word vandag gevra tussen die Lutherse Wêreldgemeenskap en die Wêreldgemeenskap van Gereformeerde Kerke.

In die Protestantse Kerk van België, waar Belhar as belydenisskrif aanvaar word, en in verskeie Noord-Amerikaanse Kerke waar Belhar as

33 Busch 2004:8-13.

34 Sien die volledige bespreking van hierdie perikoop in Calvyn se kommentaar op 1 Petrus, Calvin 2007.

35 Vir 'n verhelderende bespreking van die belangrike tema van resepsie, sien byvoorbeeld Naudé 2010:169-218.

36 Sien Die Gemeinschaft Evangelischer Kirchen in Europa (GEKE) als Gemeinschaft von Kirchen (The Community of Protestant Churches in Europe as a Fellowship of Churches), epd Dokumentation 50/51, 2011 (GEKE 2011). 
belydenisskrif ook aanvaar is of oorweeg word, word byvoorbeeld veral gevra wat versoening waarlik vandag sou kon beteken, in kontekste van radikale multi-kulturaliteit en in kontekste waar ras-verdelings nog vlak lê en telkens weer beleef word. ${ }^{37}$

In Gereformeerde Kerke in Duitsland, waar Belhar eweneens op verskillende maniere aanvaar en bely word, ${ }^{38}$ soos ook in Gereformeerde Kerke in Afrika en in prosesse binne wêreldwye Gereformeerde kringe waarin Belhar 'n inspirerende rol speel rakende ekonomiese onreg en ekologiese vernietiging, word gevra wat dit vandag prakties beteken om ontfermende geregtigheid op hierdie manier te bely en uit te leef. ${ }^{39}$

Kortom, in uiteenlopende historiese kontekste kan die voortgaande resepsie van Belhar se teologiese inhoud te make hê met 'n verskeidenheid van nuwe uitdagings en vrae. Dit is presies hoe die Gereformeerde belydenistradisie altyd gefunksioneer het. Alles is nie altyd en oral ewe relevant nie, maar enigiets in die tradisie kan op 'n dag, selfs onverwags en verrassend, nuwe aktualiteit kry in nuwe kontekste, omdat dit skielik lig werp op nuwe vrae en versoekings.

Wat die NGSK en later die VGKSA self betref moet egter gesê word dat die teologiese inhoud presies bestaan het in die innige onderlinge verband tussen die belydenis van eenheid, versoening en geregtigheid. Daar was diegene in dié kerke wat vir eenheid was - en juis daarom bang vir die taal van versoening en geregtigheid. Daar was diegene wat vir versoening was - en juis daarom nie oor eenheid of oor geregtigheid wou praat nie. Daar was diegene wat vir geregtigheid was - en juis daarom nie belang gestel het in eenheid en versoening nie. Dit was juis toe die Kerk dié drie teologiese oortuigings sáám bely het dat die Kerk werklik sy stem gevind het, sy identiteit, sy gestalte en sy getuienis. Wat dit vandág beteken om in Suid-Afrikaanse kerke dié drie temas sáám te bely is 'n vraag vir vandág, vir 25 jaar later.

37 Sien byvoorbeeld Naudé 2010:131-168; ook Botha \& Naudé 2010 en vele webwerwe van kerke in hierdie lande.

38 Sien byvoorbeeld Lippische Landeskirche 1998.

39 Sien byvoorbeeld Boesak, Weusmann \& Amjad-Ali 2010. 


\section{BIBLIOGRAFIE}

Bakhuizen Van Den Brink, J.N.

1976. De Nederlandse belijdenisgeschriften in authentieke teksten met inleiding en tekstvergelijkingen. Amsterdam: Uitgeverij Ton Bolland.

BARTH, K.

1981. The Christian life. CD IV/4. Lecture Fragments. Grand Rapids: Wm.B. Eerdmans.

BerkouWER, G.C.

1963. Vragen rondom de belijdenis. Gereformeerd theologisch tijdschrift Jrg. 63:1-41.

BoEsAK, A.A.

2009. Running with horses. Reflections of an accidental politician. Cape Town: Joho.

2011. "The doing of the little righteousness" - The ongoing search for justice after the TRC. In: L. Hansen, N.N. Koopman \& R. Vosloo (reds.). Living theology. (Wellington: BybelMedia).

Boesak, A.A., Weusmann, J. \& Amjad-Ali, C. (eds.)

2010. Dreaming a different world. Stellenbosch: Evangelisch-reformierte Kirche, Germany/Uniting Reformed Church in Southern Africa.

Botha, J.G. \& Naude, P.J.

2010. Goeie nuus om te bely. Wellington: Bybel-Media (English translation, 2010 Good news to confess. Wellington: Bible Media

1998. Op weg met Belhar. Goeie nuus vir gister, vandag en môre. Pretoria: Van Schaik.

BOTMAN, H.R.

2011. Berig van 12 Mei in Die Burger, geskryf deur Neels Jackson en beskikbaar op internet, http://www.dieburger.com/Suid-Afrika/Nuus/ Eenheid-moet-nou-volg-20110512

Braekman, E. \& De Boer, E. (Red.). 2011. Guido de Bres. Zijn leven, zijn belijden. Utrecht: Uitgeverij Kok

Burgsmüller, A. \& Weth, R. 1998. Die Barmer Theologische Erklärung. Einführung und Dokumentation. Neukirchen: Neukirchener Verlag.

Busch, E.

2004. Die Barmer Thesen 1934-2004.Göttingen: Vandenhoeck \& Ruprecht.

Calvin, J.

1960. Institutes of the Christian Religion (1559), Book IV, 1-3. Philadelphia: Westminster.

2007. Commentaries on the Catholic Epistles. Forgotten Books 
Cloete, G.D. \& Smit, D.J. (REDS.)

1982. 'n Oomblik van waarheid. Kaapstad: Tafelberg.

De VILLIERS, D.E.

2007. Perspektiven einer christlichen Verantwortungsethik. Zeitschrift für Evangelische Ethik 51(1):88-109.

Fourie, W.

2011. Communicative freedom. Wolfgang Huber's theological proposal. Münster: LIT.

GEKE

2011. Die Gemeinschaft Evangelischer Kirchen in Europa (GEKE) als Gemeinschaft von Kirchen (The Community of Protestant Churches in Europe as a Fellowship of Churches). epd Dokumentation 50/51, 2011.

HUBER, W.

1985. Folgen christlicher Freiheit. Ethik und Theorie der Kirche im Horizont der Barmer Theologischen Erklärung. Neukirchen: Neukirchener.

1990. Konflikt und Konsens. Studien zur Ethik der Verantwortung. München: Chr. Kaiser.

JONKER, W.D.

1962. Die Sendingbepalinge van die Ned. Geref. Kerk van Transvaal. Potchefstroom: Studie-groep kerk en Wêreld.

1965. Om die regering van Christus in sy kerk. Pretoria: Unisa, 1965.

1994. Bevrydende waarheid. Wellington: Hugenote-Uitgewers

KOOPMAN, N.N.

2012. Jesus Christ is Lord! An indispensable parameter for theology in public life? In Festschrift, ingedien vir publikasie.

LIPPISCHE LANDESKIRCHE

1998. Das Bekenntnis von Belhar und seine Bedeutung für die reformierten Kirchen in Deutschland. Detmold: Lippische Landeskirche.

NAUDE, P.J.

2010. Neither Calendar nor Clock. Perspectives on the Belhar Confession. Grand Rapids: Wm. B. Eerdmans.

NAUdE, P.J. \& Smit, D.J. 2000. Reception - ecumenical crisis or opportunity for South African churches? Scriptura 73(2):175-188

NooRdmans, O.

1980. Verzamelde Werken Deel VIII. Kampen: J.H. Kok.

Pelikan, J.

2003. Credo. New Haven: Yale University Press. 
Polman, A.D.R.

s.a. Woord en Belydenis I. Franeker: T. Wever.

SMIT, D.J.

1982. “...op 'n besondere wyse die God van die noodlydende, die arme en die veronregte..." In : G.D. Cloete \& D.J. Smit (reds.) 'n Oomblik van waarheid. (Kaapstad: Tafelberg), pp. 62-75, 143-159.

1984. A status confessionis in South Africa? JTSA 47:21-46.

1988. Paradigms of radical grace. On Reading Karl Barth in South Africa, VillaVicencio, C. Grand Rapids: W Eerdmans/ Cape Town: D Philip. 17-44.

2000. Versoening - en Belhar? Gereformeerd Theologisch Tijdschrift 4:159-174.

2002 Bely en beliggaam. In: P. Cortzen (red.) 350 jaar Gereformeerd/350 Years Reformed, (Bloemfontein: CLF), pp. 357-371.

2003a. A time for confession? On the WARC project 'Reformed faith and economic justice. NGTT 3\&4:478-499.

2003b. On learning to see? A Reformed perspective on the church and the poor. In: P. Couture \& B.J. Miller-McLemore (eds.) Suffering, Poverty, and HIV-AIDS: International Practical Theological Perspectives, (Cardiff: Cardiff Academic Press), pp. 55-70.

2004. "The doing of the little righteousness" - On justice in Barth's view of the Christian life. In: M. Welker \& C. Jarvis (eds.) Loving God with our minds. Festschrift for Wallace Alston, (Grand Rapids, Ml: Wm. B. Eerdmans), pp. 120-145.

2005a. On social and economic justice in South Africa today. A theological perspective on theoretical paradigms. In: A.J. Van der Walt (ed.) Theories of Social and Economic Justice, (Stellenbosch: Sun Press), pp. 225-238.

2005b. Reformed faith, justice and the struggle against apartheid. Ref World 55/4, 355-368.

2006a. "Bevrydende waarheid?" - Nagedink oor die aard van die Gereformeerde belydenis. Acta Theologica 26(1):134-158.

2006b. Barmen and Belhar in conversation - A South African perspective. NGTT 47(1\&2):291-302.

2006c. Church unity in freedom? In: M. Volf \& M. Welker (eds.) God's life in Trinity, (Augsburg: Fortress), pp. 73-92.

2007, Views on Calvin's ethics from a South African perspective. Ref World 57(4):306-344. (http://www.sek-feps.ch/media/pdf/themen/calvin09/Smit_Calvinsethics_Southafrica.pdf).

2009a. "En ook gehoor?" Vrae rondom die Gereformeerde siening van die kerk. NGTT 50:198-211. 
2009b. Reformed confession and ecumenical reception? - On the Confession of Belhar and reconciliation. In: R.R. Vosloo (ed.) Essays on Being Reformed. Collected Essays 3, (Stellenbosch: Sun Press), pp. 359-376.

2009c. lustitiae Amor - Loving Justice in the Reformed Tradition. Eugene Osterhaven Lectures, Western Theological Seminary, Holland, Ml, http://www. rca.org/Page.aspx?pid=5505

2009d. Justification and Divine Justice? In: M. Weinrich \& J.P. Burgess (eds.) What is Justification About? Reformed Contributions to an Ecumenical Theme, (Grand Rapids: Wm B Eerdmans), pp. 88-121.

2010. Calvin on the sacraments and church unity. In: N. Smit, K. Gerber \& W. Dreyer (eds.) John Calvin 1509-2009. A South African Perspective, (Potchefstroom: Conventus Reformatus Publicatio), In die Skriflig 44(4):247-270.

2011. On Self-love. Impulses from Calvin and Calvinism for Life in Society? Calvin Today. In: M. Welker, M. Weinrich \& U. Möller (eds.) Reformed Theology and the Future of the Church, (London: T \& T Clark International Continuum), pp. 158-180.

2012. The Confessio Belgica as liberating truth today? In: P. Tomson (ed.), Analecta Bruxellensia. Revue Annuelle 15, (Maastricht: Shaker Media), pp. 77-88

VAN RULER, A.A.

1954. Hoe functionneert de belijdenis? Wageningen: H. Veenman \& Zonen.

Verhey, A.

1986. Living the Heidelberg. The Heidelberg Catechism and the moral life. Grand Rapids: CRC Publications.

WELKER, M.

1986a. Security of expectations. Reformulating the theology of law and gospel. Journal of Religion 66:237-260.

1986b. Erbarmen und soziale Identität. Evangelische Kommentare 19:39-42.

1993. Dynamiken der Rechtsentwicklung in den biblischen Überlieferungen. In: O. Weinberger \& G.H. Von Wright (Hrsg.) Rechtsnorm und Rechtswirklichkeit. (Berlin: Duncker \& Humblot), pp. 779-795.

1994. God the Spirit. Minneapolis: Fortress Press.

2002. Moral, Recht und Ethos in evangelisch-theologischer Sicht. In: W. Härle \& R. Preul (Hrsg.) Ethik und Recht. (Marburg: N.G.Elwert Verlag), pp. 67-82. 
Smit Oor die Teologiese inhoud van die Belydenis van Belhar

Keywords

Belhar Confession

Reformed confessions

Church unity

Reconciliation

Justice
Trefwoorde

Belydenis van Belhar

Gereformeerde

belydenisskrifte

Kerkeenheid

Versoening

Geregtigheid 